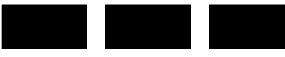 \\ F \\ THE WILLIAM DAVIDSON INSTITUTE \\ AT THE UNIVERSITY OF MICHIGAN
}

\section{Environmental Regulation and Competitiveness: Evidence from Romania}

\author{
By: Guglielmo Caporale, Christophe Rault, Robert Sova \& \\ Anamaria Sova
}

William Davidson Institute Working Paper Number 995

June 2010 


\title{
Environmental Regulation and Competitiveness: Evidence from Romania
}

\author{
Guglielmo Maria Caporale \\ Brunel University (London), CESifo and DIW Berlin ${ }^{1}$ \\ Christophe Rault \\ LEO (Laboratoire d'Economie d'Orléans), CESifo, IZA, and WDI \\ Robert Sova \\ CES, Sorbonne University, A.S.E. and E.B.R.C ${ }^{3}$ \\ Anamaria Sova \\ CES, Sorbonne University, and E.B.R.C ${ }^{4}$
}

\begin{abstract}
According to the pollution haven hypotheses differences in environmental regulation affect trade flows and plant location. Specifically, environmental stringency should decrease exports and increase imports of "dirty" goods. This paper estimates a gravity model to establish whether the implementation of more stringent regulations in Romania has indeed affected its competitiveness and decreased exports towards its European trading partners. Our findings do not provide empirical support to the pollution haven hypothesis, i.e. environmental stringency is not found to affect significantly total trade, or its components (pollution intensive trade and pollution intensive trade related to non-resource-based trade).

Key words: environmental stringency, competiveness, gravity model

JEL classification: F14, Q28

1 Centre for Empirical Finance, Brunel University, West London UB8 3PH, UK.

Email: Guglielmo-Maria.Caporale@brunel.ac.uk.

2 CNRS UMR 6221,University of Orleans, Rue de Blois-B.P.6739, 45067 Orléans Cedex 2, France.

E-mail : chrault@hotmail.com,,web-site: http://chrault3.free.fr/. (Corresponding author)

3 Center of Economics Studies Paris I, 106-112 bd. de L'Hôpital, 75647 Paris Cedex 13, France, and Academy of Bucharest University of Economics Studies, Economic \& Business Research Center E-mail: robertsova@yahoo.com. This paper has been realised within the project 92-120 (CNMP).

4 Center of Economics Studies Paris I, 106-112 bd. de L'Hôpital, 75647 Paris Cedex 13, France, and Economic \& Business Research Center, E-mail: anamariasova@yahoo.fr.
\end{abstract}




\section{Non-Technical Summary}

The transition process in the countries of Central and Eastern Europe (CEE) has brought about significant changes in their economic structure. It has also been associated with growing environmental awareness: rising pollution levels due to the development of heavy industries have increased the interest in cost-effective regulation. Romania in particular has embarked on a radical course of environmental reform, and the accession into the European Union has created a new policy focus for appropriate action.

An important topic in this context is the relationship between environment and international trade, which has recently been analysed in various empirical studies investigating the effects of environmental regulation on trade flows and export competitiveness. The issue is whether more stringent regulations might increase production costs and make pollution-intensive industries less competitive in international markets, thereby affecting the development strategies of the countries concerned. Further, according to the so-called "pollution haven" hypothesis, differences between countries in terms of environmental standards lead to a reallocation of polluting industries from those with strict environmental regulations to those with less strict policies. Thus, countries with weak environmental policies (generally with low income) become a pollution haven for those with environmental stringency, exporting the "dirty" goods and importing the "clean" ones. In contrast, the developed (high income) countries improve the quality of their environment by developing a comparative advantage in the clean goods. Typical empirical issues encountered in this type of analysis are limited data availability, measuring environmental stringency and the endogeneity of this variable.

The present study focuses on the effect of environment regulation on trade flows (exports and imports) in the case of Romania, using a gravity equation. It examines empirically whether more stringent domestic environmental policies reduce international competitiveness (more specifically, exports of the pollution-intensive products), and their general impact on trade patterns.

In most cases the environmental stringency variable in exporting countries is found to have a positive and significant effect, in contrast with the haven hypothesis which implies that stricter environmental regulation decreases exports and increases imports. However, there is no evidence 
of such an effect in the case of "dirty" trade, possibly because of a comparative advantage such that stricter environmental policies do not affect competitiveness significantly. Other factors, such a labour costs, presumably play a much more important role, environmental costs representing a very small percentage of total production costs. 


\section{Introduction}

The transition process in the countries of Central and Eastern Europe (CEE) has brought about significant changes in their economic structure. It has also been associated with growing environmental awareness: rising pollution levels due to the development of heavy industries have increased the interest in cost-effective regulation. Romania in particular has embarked on a radical course of environmental reform, and the accession into the European Union has created a new policy focus for appropriate action.

An important topic in this context is the relationship between environment and international trade, which has recently been analysed in various empirical studies investigating the effects of environmental regulation on trade flows and export competitiveness. The issue is whether more stringent regulations might increase production costs and make pollution-intensive industries less competitive in international markets, thereby affecting the development strategies of the countries concerned. Further, according to the so-called "pollution haven" hypothesis, differences between countries in terms of environmental standards lead to a reallocation of polluting industries from those with strict environmental regulations to those with less strict policies. Thus, countries with weak environmental policies (generally with low income) become a pollution haven for those with environmental stringency, exporting the "dirty" goods and importing the "clean" ones. In contrast, the developed (high income) countries improve the quality of their environment by developing a comparative advantage in the clean goods. Typical empirical issues encountered in this type of analysis are limited data availability, measuring environmental stringency and the endogeneity of this variable.

The present study focuses on the effect of environment regulation on trade flows (exports and imports) in the case of Romania, using a gravity equation. It examines empirically whether more stringent domestic environmental policies reduce international competitiveness (more specifically, exports of the pollution-intensive products), and their general impact on trade patterns. The layout of paper is as follows. Section 2 and 3 provide a brief review of the existing empirical and theoretical literature respectively. Section 4 describes the econometric framework used for the analysis. Section 5 presents the empirical results. Section 6 offers some concluding remarks. 


\section{Empirical studies}

The empirical evidence on the environment-trade nexus is mixed. The most common finding is that strict environmental regulations do not affect trade flows and international competitiveness (Tobey, 1990; Harris and al., 2002). Only a few studies conclude that they lead to a loss of competiveness for pollution-intensive goods (Van Beers and van den Bergh, 1997). However, even if more stringent regulations initially mean lower competitiveness and smaller market shares reflecting higher production costs, they might also stimulate innovation, improve productivity and increase exports in the long run (this is the so-called Porter hypothesis - see Porter and van der Linde, 1995).

Tobey (1990) used a cross-section Heekscher-Ohlin-Vanek (HOV) model of international trade and found that the introduction of stringent environmental measures had not caused trade patterns to deviate from the HOV predictions. Van Beers and van den Bergh (1997) estimated an equation for bilateral trade flows introducing two variables for environmental stringency (a broad one and a narrow one based on the energy intensity) in a gravity model. The results, using a sample of 21 OECD countries, indicate that the impact of stricter regulations on export and import flows is negative. Van Beers and van den Bergh (2000) revisited the analysis of Tobey (1990) using more disaggregated data and partly confirmed his results. Xu (2000) also estimated a gravity model, finding evidence that new trade barriers emerge to offset the effects of more stringent environmental regulations, and that the trade pattern of environmentally sensitive goods remain unchanged. Harris et al. (2002) used a triple indexed fixed effects model (import, export and time effects), and showed that, once these effects are taken into consideration, the impact of environmental stringency on international trade becomes statistically insignificant.

Jug and Mirza (2005) proposed an alternative explanation for the low and insignificant effect of strict environmental policies on trade flows which is not related to environmental features but rather to the degree of product differentiation. They showed that stringency matters less in the case of trade in highly differentiated products due to their lower price elasticity.

Ederington and Minier (2003) investigated the hypothesis that environmental policy has been used as a secondary trade barrier, and estimated the impact of environmental regulation on trade flows when environmental policy is modelled endogenously, finding that its estimated 
effect on trade flows is significantly higher than reported in previous studies affected by endogeneity bias.

Levinson and Taylor (2008) showed how unobserved heterogeneity, endogeneity and aggregation issues generate biases when estimating the relationship between regulatory costs and trade. They used data on US regulations and net trade flows between the US, Canada and Mexico for 130 manufacturing industries from 1977 to 1986, and reported that the estimated effects of pollution costs on net imports are positive and statistically significant. Also, the 2SLS estimates are larger than the fixed-effects ones.

\section{Theory}

In the theoretical literature there are two major hypotheses linking the environment and trade flows, more precisely the pollution haven and the factor endowments ones. The former predicts that countries where environmental policy (regulation) is relatively weak will tend to specialise in pollution intensive (or "dirty") industries. Generally, countries with lax environmental regulations are low-income countries. By contrast, the latter predicts that differences in factor endowments determine trade patterns and environmental policy has only a minor effect. Thus, this hypothesis suggests that countries with abundant capital will specialise in and export capital intensive goods, and countries with abundant labour will export labour intensive good, regardless of environmental regulations ${ }^{5}$.

Let us consider the haven pollution theory using a model with production -generated pollution. The model assumes that there are two goods, $\mathrm{X}$ and $\mathrm{Y}$, where $\mathrm{X}$ is the dirty good (which generates pollution during the production) and $\mathrm{Y}$ is the clean good (which does not pollute).

The production function for good Y using the two factors capital and labour takes the following form:

$$
\mathrm{Y}=\mathrm{F}(\mathrm{K}, \mathrm{L})
$$

\footnotetext{
${ }^{5}$ In this paper we will only focus on the haven hypothesis and will not test empirically the factor endowment hypothesis.
} 
and for good X:

$$
X=(1-\theta) G(K, L)
$$

where: $\theta$ represents the abatement effort and lies in the interval between 0 and $1(0<\theta<1)$ : if $\theta$ $=0$, there is no abatement effort and pollution rises with the output of the dirty good (X); if $\theta$ rises, this leads to an increase in the abatement effort and a decrease in the production of $\mathrm{X}$ and implicitly pollution.

If it is assumed that $\mathrm{X}$ produces emissions and these are generated in the production process, then total emissions are given by $\mathrm{E}=\mathrm{eX}$, where $\boldsymbol{e}$ represents emission intensity. The model also assumes that there are two countries, one rich (A - high income) and the other poor (B - low income). A simple supply and demand analysis is used to determine the price under autarchy in the two countries.

The pollution haven model assumes that trading countries are identical with the exception of the differences in emission intensity. Therefore their supply curves will also differ, being a function of the price (p), emission intensity (e), capital/labour (K/L) and taking the following form:

$$
R S(p, e, K / L)=\frac{X(p, e, K / L)}{Y(p, e, K / L)}
$$

When the price and emission intensity increase, the supply of good $\mathrm{X}$ relative to good $\mathrm{Y}$ increases.

In contrast, the demand curve is the same for the two countries because preferences over goods are supposed to be homothetic. Specifically, the demand curve for good $\mathrm{X}$ relative to good $\mathrm{Y}$ is a function of the prices in the two countries:

$$
R D_{X / Y}(p)=\frac{b_{x}(p)}{b_{y}(p)}
$$

If countries are identical, their supply curve (RS) is the same and so are prices, implying that there is no trade. If emission intensity differs and is higher in the low-income country, then weak 
environmental regulation will lead to more production of the dirty good in this country (B) and to a decline in the production of the clean good due to the reallocation of resources from $\mathrm{Y}$ to $\mathrm{X}$.

The pollution haven hypothesis can be illustrated as in the figure below:

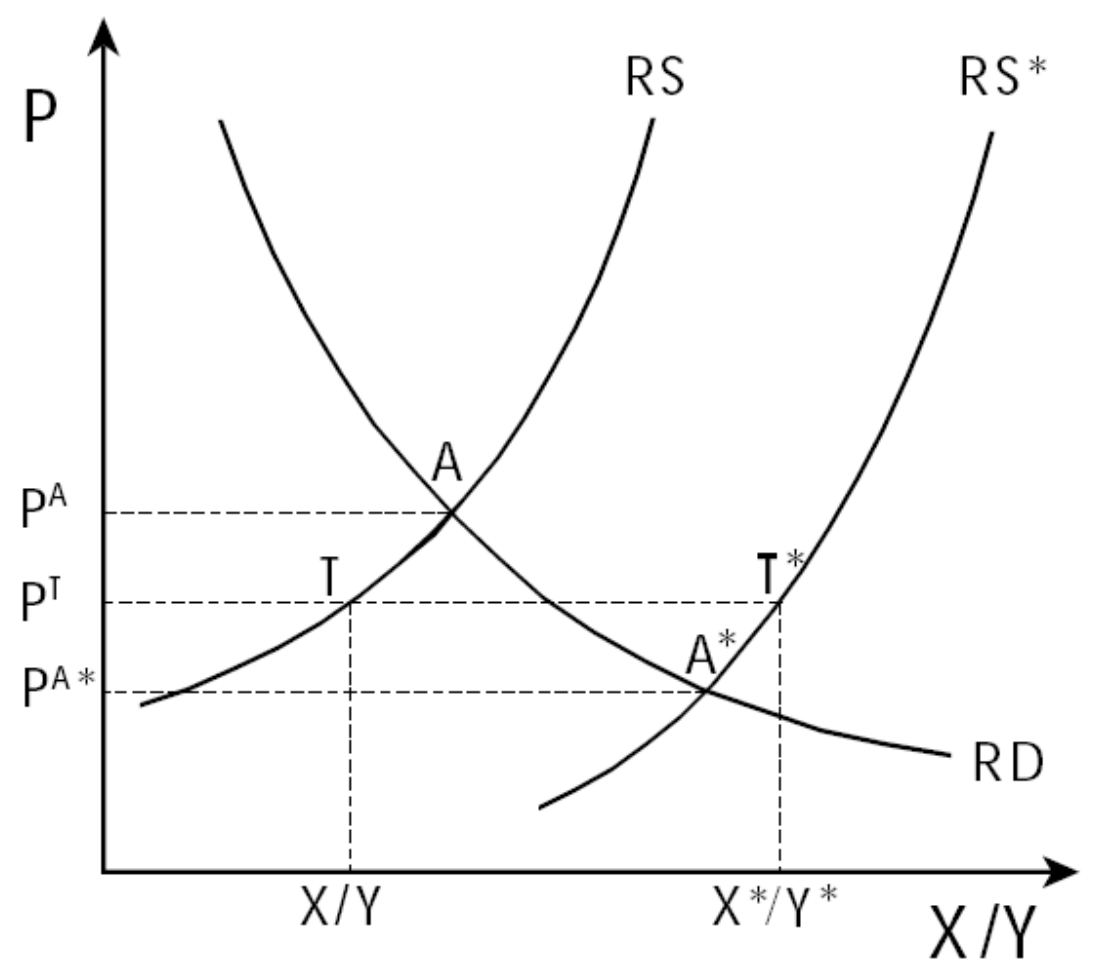

Source: Copeland and Taylor (2003)

The price of the dirty good $(\mathrm{X})$ in the developed country is higher then in the developing country $\left(\mathrm{P}^{\mathrm{A}}>\mathrm{P}^{\mathrm{A}^{*}}\right)^{6}$ due to the fact that in the former pollution taxes are higher, and therefore the price of $\mathrm{X}$ under autarchy is higher. Consequently, the production of $\mathrm{X}$ declines in the developed country but increases in the developing country. Thus, the relative supply of the country with weak environmental regulations will shift out to the right (RS*). Hence, the high income country will produce and export more of the clean good $\mathrm{Y}$ and will import the dirty good $\mathrm{X}$ from the low income country, whilst the low income country will export $X$. The pollution level will increase in the developing countries with weak pollution policy and will decrease in the developed countries with stringent pollution policy, and the former will provide pollution havens for dirty industries.

\footnotetext{
${ }^{6}$ We use the asterisk for the developing country variables.
} 
The differences in pollution policy could lead to the migration of the pollution intensive industries from developed to developing economies in the presence of less stringent environmental regulations, low wages and resource abundance in the latter. Then, an increase in the stringency of environmental regulations will imply a loss of competitiveness for dirty industries and lower exports of dirty goods. Clearly, if the effects of changes in pollution regulations (pollution abatement costs) are modest, then it becomes difficult to maintain the pollution haven hypothesis.

\section{The econometric framework}

The gravity model is extensively used in the empirical literature on international trade. The first studies estimating it were those of Linnemann (1966) and Tinbergen (1962). Its theoretical foundations were developed later by Anderson (1979), Bergstrand (1985) and Helpman and Krugman (1985). This model is also used to test the link between the environmental stringency and trade flows (Van Beers and Van den Bergh, 1997, Harris et al. 2002; Jug and Mirza, 2005). The standard equation takes the following form:

$$
T_{i j t}=\beta_{0}+\beta_{1} S_{i j t}+X^{\prime} \beta+u_{i j t}
$$

where $T_{i j t}$ represents trade flows between trading partners $(\boldsymbol{i}$ and $\boldsymbol{j}), S_{i j t}$ is a measure of environmental stringency, $X^{1}$ stands for other variables which differ across countries, $\beta_{0}$ is the constant and $u_{i j t}$ is the error term which captures the measurement errors and is assumed to be independently identically distributed.

To examine the impact of environmental regulations on trade flows (export and imports), we follow Anderson and van Wincoop (2003), whose model takes into account multilateral trade resistance (MTR) unlike the "classic version" of the gravity model. As they argue, it is essential to analyse not only bilateral resistance to trade (trade barriers between two countries $i$ and j) but also multilateral resistance, i.e. trade barriers between each country $i$ or $j$ and all its partners. Intuitively, a country has more incentives to trade with a partner when its trade resistance with all other partners is higher. This results in price differences between countries, ignoring which may bias the estimates of all the other variables in the gravity equation. 


\subsection{The Anderson and van Wincoop model}

The Anderson and van Wincoop model (2003) is based on assumptions such as constant elasticity of substitution, differentiation of goods by origin and country specialisation in their variety. Exports costs (transport costs, information costs, differences in legislation, etc.) are borne by the importer and are symmetrical. The model introduces multilateral resistance to trade in addition to the bilateral one. The former represents the average cost of imports whatever their origin, while the latter concerns import costs between a pair of countries. The modified gravity equation has the following form:

$$
X_{i j}=\frac{Y_{t} Y_{j}}{Y^{w}} \times\left(\frac{T_{i j}}{P_{i} P_{j}}\right)^{1-\sigma}
$$

where $\boldsymbol{X}_{\boldsymbol{i j}}$ represents exports of country $\boldsymbol{i}$ towards country $\boldsymbol{j} ; \boldsymbol{Y}_{\boldsymbol{t}}, \boldsymbol{Y}_{\boldsymbol{j}}$ stand for income of country $\boldsymbol{i}$ and $\boldsymbol{j}$ respectively and $Y^{w}=\sum_{k=1}^{K} Y_{k}$ is total income; $\boldsymbol{T}_{\boldsymbol{i} \boldsymbol{j}}$ represents bilateral resistance (import costs between country $\boldsymbol{i}$ and $\boldsymbol{j}) ; \boldsymbol{P}_{\boldsymbol{i}}, \boldsymbol{P}_{\boldsymbol{j}}$ are the price index of country $\boldsymbol{i}$ and $\boldsymbol{j}$ respectively and represent multilateral resistance for the two countries; $\sigma$ is the demand elasticity which is assumed to be greater than unity.

Bilateral trade resistance $\left(\mathrm{T}_{\mathrm{ij}}\right)$ is a vector of observable variables affecting bilateral trade costs between country $\mathrm{i}$ and country $\mathrm{j}$ such as geographical distance $\left(\mathrm{D}_{\mathrm{ij}}\right)$, common border $\left(\mathrm{FRT}_{\mathrm{ij}}\right)$, common language $\left(\mathrm{LANG}_{\mathrm{ij}}\right)$, existence of colonial relations $\left(\mathrm{RL}_{\mathrm{ij}}\right)$ and membership of trade agreements $\left(\mathrm{ACR}_{\mathrm{ij}}\right)$.

$$
T_{i j}=\left(D_{i j}\right)^{\delta_{1}}\left\lfloor e^{\delta_{2} R L_{i j}+\delta_{3} F R T_{i j}+\delta_{3} L A N G_{i j}+\delta_{4} A C R_{i j}}\right\rfloor
$$

Bilateral resistence $\left(\mathrm{T}_{\mathrm{ij}}\right)$ represents the price of the foreign variety relative to the local variety and it is assumed to be symmetric $\left(T_{i j}=T_{j i}\right)$. The price indices for consumption $\left(P_{i}, P_{j}\right)$ for country $\mathrm{i}$ and $\mathrm{j}$ are defined as follows: 


$$
P_{i}=\left[\sum_{j=1}^{N}\left(\beta_{j} p_{j} t_{i j}\right)^{1-\sigma}\right]^{1 /(1-\sigma)} \quad P_{j}=\left[\sum_{i=1}^{N}\left(\beta_{i} p_{i} t_{i j}\right)^{1-\sigma}\right]^{1 /(1-\sigma)}
$$

where $\beta_{i(j)}^{1-\sigma}=\theta_{j(i)}=Y_{j(i)} / Y^{w}$ is the share of country $\boldsymbol{j}(\boldsymbol{i})$ in total income. Anderson and van Wincoop (2003) interpret $\boldsymbol{P}_{\boldsymbol{i}}$ and $\boldsymbol{P}_{\boldsymbol{j}}$ as multilateral trade resistance since each is a function of all bilateral resistance variables (e.g., $\boldsymbol{P}_{\boldsymbol{i}}$ for country I is the average of $\boldsymbol{T}_{\boldsymbol{i} \boldsymbol{j}}$ )

Thus, the gravity equation used to control for the effects of multilateral resistance takes the following form:

$$
\log \left(X_{i j t}\right)=a_{0}+a_{1} \log \left(G D P_{i t}\right)+a_{2} \log \left(G D P_{j t}\right)+a_{3} \log \left(D I S T_{i j}\right)+a_{4} B R D_{i j}+a_{5} E T N_{i j}+u_{i j}+\lambda_{t}+\varepsilon_{i j t}
$$

where :

- $\mathrm{X}_{\mathrm{ijt}}=$ exports from country $\mathrm{i}$ towards country $\mathrm{j}$, in year $\mathrm{t}$; millions of dollars, (database : COMTRADE) ;

- $\mathrm{GDP}_{\mathrm{it}(\mathrm{jt})}=$ Gross domestic product of countries $\mathrm{i}$ and $\mathrm{j}$, in year $\mathrm{t}$, at purchasing power parity (PPP); millions of dollars, (database : Chelem-CEPII) ;

- $\quad \operatorname{DIST}_{\mathrm{ij}}=$ geographical distance between the capitals of country $\mathrm{i}$ and country $\mathrm{j}$ respectively; kilometers, (Chelem-CEPII) ;

- $\quad \mathrm{BRD}_{\mathrm{ij}}=$ dummy variable for common border $; \mathrm{FRT}=1$ if $\mathrm{i}$ and $\mathrm{j}$ have a common border and 0 otherwise ;

- $\quad \mathrm{ETN}_{\mathrm{ij}}=$ dummy variable for the existence of a common minority group; $\mathrm{ETN}_{\mathrm{ij}}=1$ if the two countries $\mathrm{i}$ and $\mathrm{j}$ have a common minority group and 0 otherwise ;

- $\mathrm{u}_{\mathrm{ij}}=$ couple fixed effects for controlling multilateral resistance;

- $\quad \lambda_{\mathrm{t}}=$ time fixed effects;

- $\varepsilon_{\mathrm{ijt}}$ : error term

The expected signs for the coefficients of the variables included in the model are based on theory. For instance, we expect a positive effect on trade flows of variables such as the size of a country, common border and common minority group and a negative impact of geographic 
distance (which is a proxy for transport costs, tariffs, non-tariff barriers and informal barriers). Supply of exports and demand for imports are a positive function of the income level in the partner countries. As for the coefficient of environmental stringency for exporter and importer, $\boldsymbol{S} \boldsymbol{T}_{\boldsymbol{i}}$ and $\boldsymbol{S} \boldsymbol{C}_{\boldsymbol{j}}$ are expected to have a negative and positive effect respectively on the basis of the pollution haven hypothesis.

\subsection{Data}

Our panel spans over a period of 9 years (1999-2007) and includes 20 countries, namely Germany, Austria, Italy, United Kingdom, Spain, Netherlands, Belgium, Portugal, Finland, Sweden, Bulgaria, Estonia, Hungary, Latvia, Lithuania, Poland, Romania, Slovakia, Slovenia, Cyprus.

As data for environmental stringency are not generally available, proxies are normally used in empirical studies, for instance an index based on energy intensity (Harris et al., 2002), an index developed by the World Bank (Xu, 2000), PACE as a fraction of value added (Levinson and Taylor, 2008) or an index developed by Eurostat ( Jug and Mirza, 2005). We use data from Eurostat which provides environmental data for the European Union countries (EU-27). Total current expenditure, which represents expenditure for environmental protection activities, is the chosen proxy for environmental stringency and a measure of abatement costs. We exclude from our sample some countries such as France, Denmark, Ireland, Luxembourg, the Czech Republic and Greece due to data constraints. Data on bilateral trade (exports and imports) are extracted from the COMTRADE database at total level and by sectors. The GDP data are obtained from the IMF, while distance, common border come from CEPII database.

We consider the following pollution intensive sectors ("dirty" sectors): (251) pulp and waste paper, (334) petroleum products, (335) residual petroleum products, (51) organic chemicals, (52) inorganic chemicals, (562) fertilizers, (59) chemical materials, (634) veneers, plywood, (635) wood manufactures; (64) paper paperboard, (68) non-ferrous metals; (661) lime, cement, construction materials, (67) iron and steel, (69) metal manufactures (we use the classification of dirty industries of Low, 1992). For the pollution intensive trade related to nonresource-based trade (footloose sectors) we include the following sectors: (59) chemical materials, (661) lime, cement, construction materials and (69) metals manufactures. 
An important econometric issue is the potential endogeneity of the environmental stringency variable. Some studies try to deal with it by using the 2SLS method (Ederington and Minier, 2003, Levinson and Taylor, 2008) or a three -way fixed effect model which allows for exporter, importer and time specific effects (Harris and al. 2002). In the present study, we shall use instead the fixed effect vector decomposition method (FEVD) proposed by Plümper and Tröeger (2004). This estimator controls for the potential endogeneity of all right-hand-side variables, including environmental stringency, thereby removing this possible bias source, and also yields more efficient estimates. Also, the presence of fixed effects allows to take into account multilateral resistance. Further, it has desirable finite-sample properties.

\section{Empirical results}

In order to analyse the impact of environmental stringency on the trade flows we estimate models for total trade flows (exports and imports) as well as trade of the pollution intensive sectors only; we also distinguish between pollution intensive sectors and non-resource-based sectors (footloose). The results for total trade (exports and imports) are reported in Table 1.

Table 1: Estimation results of the impact of environmental stringency on total trade

\begin{tabular}{|c|c|c|c|c|c|c|}
\hline \multirow[t]{3}{*}{ Variables } & \multicolumn{2}{|c|}{$\begin{array}{c}\text { Total trade } \\
\text { (FEVD) }\end{array}$} & \multicolumn{2}{|c|}{$\begin{array}{c}\text { Export } \\
\text { (FEVD) }\end{array}$} & \multicolumn{2}{|c|}{$\begin{array}{l}\text { Import } \\
\text { (FEVD) }\end{array}$} \\
\hline & (1) & (2) & (3) & (4) & $(5)$ & (6) \\
\hline & $\mathbf{x}_{\mathrm{iji}}$ & $\mathbf{x}_{\mathrm{ijt}}$ & $\mathbf{x}_{\mathrm{ijt}}$ & $\mathbf{x}_{\mathrm{ijt}}$ & $\mathbf{x}_{\mathrm{ijt}}$ & $\mathbf{x}_{\mathrm{ijt}}$ \\
\hline \multirow[t]{2}{*}{ GDP $_{\text {it }}$} & 1.216 & 1.056 & 0.751 & 0.621 & 2.297 & 1.900 \\
\hline & $(62.09)^{* * *}$ & $(10.02)^{* * *}$ & $(1.93)^{*}$ & $(2.31)^{* *}$ & $(67.47) * * *$ & $(9.43) * * *$ \\
\hline \multirow[t]{2}{*}{$\mathbf{G D P}_{\mathbf{j t}}$} & 2.739 & 2.746 & 1.961 & 1.803 & 1.837 & 2.119 \\
\hline & $(84.13)^{* * *}$ & $(25.41)^{* * *}$ & $(23.87)^{* * *}$ & $(20.14)^{* * *}$ & $(14.62)^{* * *}$ & $(12.05)^{* * *}$ \\
\hline \multirow[t]{2}{*}{ DIST $_{i j}$} & -1.048 & -1.098 & -1.620 & -1.508 & -1.265 & -1.605 \\
\hline & $(39.57) * * *$ & $(36.06)^{* * *}$ & $(54.05)^{* * *}$ & $(31.04)^{* * *}$ & $(28.36) * * *$ & $(25.78)^{* * *}$ \\
\hline \multirow[t]{2}{*}{$\mathbf{B R D}_{\mathrm{ij}}$} & 0.072 & 0.107 & 0.242 & 0.216 & 0.206 & 0.134 \\
\hline & $(2.31)^{* *}$ & $(17.84)^{* * *}$ & $(34.92)^{* * *}$ & $(39.91)^{* * *}$ & $(5.59) * * *$ & $(11.76)^{* * *}$ \\
\hline \multirow[t]{2}{*}{$\mathbf{E T N}_{\text {it }}$} & 0.237 & 0.219 & 0.046 & 0.032 & 0.386 & 0.322 \\
\hline & $(8.12)^{* * *}$ & $(42.39) * * *$ & $(51.88)^{* * *}$ & $(49.20)^{* * *}$ & $(11.57)^{* * *}$ & $(44.16) * * *$ \\
\hline \multirow[t]{2}{*}{$\mathbf{S T}_{\mathrm{it}}$} & - & 0.239 & - & 0.021 & - & 0.344 \\
\hline & - & $(18.05)^{* * *}$ & - & $(0.46)$ & - & $(30.43)^{* * *}$ \\
\hline $\mathbf{S T}_{\mathbf{j t}}$ & - & 0.059 & - & 0.083 & - & -0.140 \\
\hline
\end{tabular}




\begin{tabular}{|c|c|c|c|c|c|c|}
\hline & - & $(4.45)^{* * *}$ & - & $(9.03) * * *$ & - & $(0.96)$ \\
\hline$\lambda_{t}$ & yes & Yes & yes & yes & yes & yes \\
\hline \multirow{2}{*}{ Residuals } & 1.000 & 1.000 & 1.000 & 1.000 & 1.000 & 1.000 \\
\hline & $(49.90) * * *$ & $(29.99)^{* * *}$ & $(63.15)^{* * *}$ & $(60.14)^{* * *}$ & $(29.18)^{* * *}$ & $(54.78) * * *$ \\
\hline \multirow[t]{2}{*}{ Constant } & -0.302 & -0.409 & 7.167 & 6.807 & 0.037 & -1.674 \\
\hline & $(2.01)^{* *}$ & $(42.06)^{* * *}$ & $(89.45)^{* * *}$ & $(69.83)^{* * *}$ & $(0.10)$ & $(24.13) * * *$ \\
\hline Observations & 342 & 342 & 171 & 171 & 171 & 171 \\
\hline R-squared & 0.81 & 0.87 & 0.89 & 0.93 & 0.92 & 0.98 \\
\hline \multicolumn{7}{|c|}{ t statistics in parentheses } \\
\hline
\end{tabular}

Note: FEVD stands for the Fixed Effects Decomposition method.

As can be seen, the estimated coefficients are almost always significant and have the expected theoretical signs. The size variable of the exporting country and the partner country appear to be two of the main determinants of trade flows between Romania and the EU-27. The proxy for environmental stringency in the exporter country has a positive impact on trade flows in all cases, implying that the hypothesis that stricter environmental regulation decreases exports and affects competiveness can be rejected. Besides, this variable becomes insignificant when exports of Romania towards its trading partners in the EU-27 are considered. Presumably there are more important factors affecting trade, such as low wages, regardless of environmental regulations. Environmental costs appear to play a marginal role and do not affect trade flows significantly. Environmental stringency in the importer country has a positive and significant effect on trade flows and exports, but a negative and insignificant one on imports. As for the other variables, their estimated effects are consistent with the predictions of the gravity model. Geographical distance has a negative impact on trade volume, whilst common border or common minority group have a positive one.

Next, we focus our attention on the impact of environmental stringency on the pollution intensive sectors. Following the classification of the "dirty" industries of Low (1992) we consider the 14 "dirty" sectors. Both the sample and the econometric methods used are the same as before. The results are presented in Table 2 . 
Table 2: Estimation results of the impact of environmental stringency on the "dirty" trade

\begin{tabular}{|c|c|c|c|c|c|c|}
\hline \multirow[t]{3}{*}{ Variables } & \multicolumn{2}{|c|}{$\begin{array}{c}\text { Total trade } \\
\text { (FEVD) }\end{array}$} & \multicolumn{2}{|c|}{$\begin{array}{c}\text { Export } \\
\text { (FEVD) }\end{array}$} & \multicolumn{2}{|c|}{$\begin{array}{l}\text { Import } \\
\text { (FEVD) }\end{array}$} \\
\hline & (1) & (2) & (3) & (4) & (5) & (6) \\
\hline & $\mathbf{x}_{\mathrm{ijt}}$ & $\mathbf{x}_{\mathrm{iji}}$ & $\mathbf{x}_{\mathrm{iji}}$ & $\mathbf{x}_{\mathrm{ijt}}$ & $\mathbf{x}_{\mathrm{ijt}}$ & $\mathbf{x}_{\mathbf{i j t}}$ \\
\hline \multirow{2}{*}{ GDP $_{\text {it }}$} & 1.217 & 1.257 & 1.665 & 1.846 & 0.580 & 0.546 \\
\hline & $(48.88)^{* * *}$ & $(49.33) * * *$ & $(12.23) * * *$ & $(11.42)^{* * *}$ & $(21.83)^{* * *}$ & $(20.13)^{* * *}$ \\
\hline \multirow[t]{2}{*}{$\mathbf{G D P}_{\mathbf{j t}}$} & 0.798 & 0.832 & 0.269 & 0.281 & 1.294 & 1.287 \\
\hline & $(34.69)^{* * *}$ & $(35.94) * * *$ & $(11.73)^{* * *}$ & $(11.77)^{* * *}$ & $(9.03)^{* * *}$ & $(7.17)^{* * *}$ \\
\hline \multirow[t]{2}{*}{ DIST $_{\mathbf{i j}}$} & -1.491 & -1.286 & -0.445 & -0.399 & -1.126 & -1.077 \\
\hline & $(25.34) * * *$ & $(23.91) * * *$ & $(5.55) * * *$ & $(4.46)^{* * *}$ & $(13.29) * * *$ & $(11.38)^{* * *}$ \\
\hline \multirow[t]{2}{*}{$\mathbf{B R D}_{\mathrm{ij}}$} & 0.321 & 0.254 & 0.308 & 0.297 & 0.402 & 0.368 \\
\hline & $(17.13)^{* * *}$ & $(17.53) * * *$ & $(8.58)^{* * *}$ & $(7.69)^{* * *}$ & $(8.43)^{* * *}$ & $(8.16)^{* * *}$ \\
\hline \multirow[t]{2}{*}{$\mathbf{E T N}_{\mathrm{ij}}$} & 0.005 & 0.017 & 0.228 & 0.211 & 0.246 & 0.269 \\
\hline & $(0.16)$ & $(0.49)$ & $(4.95)^{* * *}$ & $(4.37)^{* * *}$ & $(5.38) * * *$ & $(5.12)^{* * *}$ \\
\hline \multirow[t]{2}{*}{$\mathbf{S T}_{\mathrm{it}}$} & - & 0.115 & - & 0.284 & - & 0.076 \\
\hline & - & $(2.53) * * *$ & - & $(2.16)^{* *}$ & - & $(0.24)$ \\
\hline \multirow{2}{*}{$\mathbf{S T}_{\mathbf{j t}}$} & - & 0.037 & - & 0.112 & - & -0.053 \\
\hline & - & $(0.78)$ & - & $(1.80)^{*}$ & - & $(0.34)$ \\
\hline$\lambda_{t}$ & yes & yes & yes & yes & yes & yes \\
\hline \multirow{2}{*}{ Residuals } & 1.000 & 1.000 & 1.000 & 1.000 & 1.000 & 1.000 \\
\hline & $(110.84)^{* * *}$ & $(106.62)^{* * *}$ & $(75.31)^{* * *}$ & $(74.92) * * *$ & $(68.92)^{* * *}$ & $(68.71)^{* * *}$ \\
\hline \multirow[t]{2}{*}{ Constant } & 0.558 & 0.441 & -2.246 & -2.964 & -0.589 & -0.650 \\
\hline & $(3.25)^{* * *}$ & $(2.48)^{* *}$ & $(5.75)^{* * *}$ & $(6.41)^{* * *}$ & $(1.43)$ & $(1.34)$ \\
\hline Observations & 4788 & 4788 & 2394 & 2394 & 2394 & 2394 \\
\hline R-squared & 0.74 & 0.79 & 0.73 & 0.80 & 0.79 & 0.84 \\
\hline
\end{tabular}

Note: FEVD stands for the Fixed Effects Decomposition method.

As before, size, common border and common minority group have a positive effect, whilst geographical distance has a negative one. Concerning the impact of environmental stringency, it is estimated to be positive in the case of the exporting countries, perhaps because these have a comparative advantage for dirty exports such that stricter environmental policies do not affect their competitiveness. The sign is the same for importing countries. No statistically significant effect on "dirty" imports is found. 
Finally, we estimated the model for "dirty" and footloose sectors separately. From the former we selected those with a sizeable weight in total trade, namely for exports iron and steel (67), petroleum products (334) and non-ferrous metals (68), and for imports metals manufactures (69), sectors iron and steel (67) and paper paperboard (64). The footloose sectors are chemical materials, lime, cement, construction materials and metals manufactures. These sectors are supposed to respond significantly to changes in the stringency of environmental regulations.

The results are shown in Table 3 and 4 respectively. In the case of "dirty" trade, environmental regulations in exporting and importing countries have a positive and significant effect on exports of each sector but no effect on imports. As for the footloose sectors, the coefficients are not statistically significant, indicating that environmental costs do not have an impact on such trade flows between Romania and its European partners. 
Table 3: Estimation results of the impact of environmental stringency on "dirty" exports and imports

\begin{tabular}{|c|c|c|c|c|c|c|}
\hline \multirow{3}{*}{ Sectors } & \multicolumn{3}{|c|}{$\begin{array}{c}\text { Export } \\
\text { (FEVD) }\end{array}$} & \multicolumn{3}{|c|}{$\begin{array}{l}\text { Import } \\
\text { (FEVD) }\end{array}$} \\
\hline & 67 & 334 & 68 & 69 & 67 & 64 \\
\hline & $\mathbf{x}_{\mathrm{ijt}}$ & $\mathbf{x}_{\mathbf{i j t}}$ & $\mathbf{x}_{\mathrm{ijt}}$ & $\mathbf{x}_{\mathrm{ijt}}$ & $\mathbf{x}_{\mathrm{ijt}}$ & $\mathbf{x}_{\mathrm{ijt}}$ \\
\hline \multirow[t]{2}{*}{ GDP $_{\text {it }}$} & 1.079 & 1.210 & 0.819 & 0.964 & 2.028 & 1.091 \\
\hline & $(2.54)^{* * *}$ & $(4.30)^{* * *}$ & $(9.17)^{* * *}$ & $(10.42)^{* * *}$ & $(13.29)^{* * *}$ & $(4.70) * * *$ \\
\hline \multirow[t]{2}{*}{ GDP $_{\text {it }}$} & 1.186 & 1.343 & 1.105 & 1.172 & 1.039 & 1.633 \\
\hline & $(10.21)^{* * *}$ & $(9.31)^{* * *}$ & $(10.16)^{* * *}$ & $(11.75)^{* * *}$ & $(1.87)^{*}$ & $(3.11)^{* * *}$ \\
\hline \multirow[t]{2}{*}{$\mathbf{S T}_{\text {it }}$} & 1.292 & 1.159 & 0.885 & -0.045 & 0.019 & -0.077 \\
\hline & $(2.54)^{* *}$ & $(3.17)^{* * *}$ & $(2.65)^{* * *}$ & $(0.36)$ & $(0.11)$ & $(0.44)$ \\
\hline \multirow[t]{2}{*}{$S \mathbf{T}_{\mathbf{j t}}$} & 0.185 & 0.314 & 0.278 & 0.381 & -0.116 & 0.402 \\
\hline & $(0.75)$ & $(2.20)^{* *}$ & (1.13) & $(1.00)$ & $(0.21)$ & $(0.76)$ \\
\hline \multirow[t]{2}{*}{ DIST $_{i j}$} & -1.907 & -1.232 & -1.455 & -0.302 & -1.264 & -1.373 \\
\hline & $(12.70)^{* * *}$ & $(5.36)^{* * *}$ & $(5.79)^{* * *}$ & $(1.81)^{*}$ & $(11.74) * * *$ & $(4.34)^{* * *}$ \\
\hline \multirow[t]{2}{*}{ BRD $_{i j}$} & 0.149 & 0.207 & 0.126 & 0.573 & 0.621 & 0.478 \\
\hline & $(12.45)^{* * *}$ & $(4.37)^{* * *}$ & $(3.87)^{* * *}$ & $(5.65)^{* * *}$ & $(7.10)^{* * *}$ & $(6.80)^{* * *}$ \\
\hline \multirow[t]{2}{*}{$\mathbf{E T N}_{\mathrm{ij}}$} & 0.169 & 0.153 & 0.117 & 0.051 & 0.208 & 0.194 \\
\hline & $(2.81)^{* * *}$ & $(3.49)^{* * *}$ & $(3.13)^{* * *}$ & $(0.42)$ & $(1.96)^{*}$ & $(1.15)$ \\
\hline \multirow[t]{2}{*}{ Residuals } & 1.000 & 1.000 & 1.000 & 1.000 & 1.000 & 1.000 \\
\hline & $(17.61)^{* * *}$ & $(10.85)^{* * *}$ & $(14.84) * * *$ & $(32.79) * * *$ & $(21.33) * * *$ & $(22.17)^{* * *}$ \\
\hline \multirow[t]{2}{*}{ Constant } & 2.550 & -2.064 & -1.518 & -2.399 & 4.185 & -0.055 \\
\hline & $(3.44)^{* * *}$ & $(0.98)$ & $(0.70)$ & $(8.03)^{* * *}$ & $(2.94)^{* * *}$ & $(0.03)$ \\
\hline Observations & 171 & 171 & 171 & 171 & 171 & 171 \\
\hline R-squared & 0.73 & 0.62 & 0.69 & 0.91 & 0.78 & 0.80 \\
\hline \multicolumn{7}{|c|}{$\mathrm{t}$ statistics in parentheses } \\
\hline & & & & & & \\
\hline
\end{tabular}


Table 4: Estimation results of the environmental stringency impact on the export and import non resources based sectors

\begin{tabular}{|c|c|c|c|c|c|c|}
\hline \multirow{3}{*}{ Variables } & \multicolumn{2}{|c|}{$\begin{array}{l}\text { Total trade } \\
\text { (FEVD) }\end{array}$} & \multicolumn{2}{|c|}{$\begin{array}{c}\text { Export } \\
\text { (FEVD) }\end{array}$} & \multicolumn{2}{|c|}{$\begin{array}{l}\text { Import } \\
\text { (FEVD) }\end{array}$} \\
\hline & (1) & (2) & (3) & (4) & (5) & (6) \\
\hline & $\mathbf{x}_{\mathrm{ijt}}$ & $\mathbf{x}_{\mathrm{ijt}}$ & $\mathbf{x}_{\mathrm{ijt}}$ & $\mathbf{x}_{\mathrm{ijt}}$ & $\mathbf{x}_{\mathrm{ijt}}$ & $\mathbf{x}_{\mathrm{ijt}}$ \\
\hline \multirow[t]{2}{*}{ GDP $_{\text {it }}$} & 0.768 & 0.821 & 1.439 & 1.307 & 1.973 & 2.053 \\
\hline & $(18.12)^{* * *}$ & $(19.69)^{* * *}$ & $(5.93) * * *$ & $(4.76)^{* * *}$ & $(21.13) * * *$ & $(19.04)^{* * *}$ \\
\hline \multirow{2}{*}{$\mathbf{G D P}_{\mathbf{j t}}$} & 1.982 & 2.020 & 0.415 & 0.477 & 1.501 & 1.474 \\
\hline & $(40.30)^{* * *}$ & $(39.58)^{* * *}$ & $(9.25)^{* * *}$ & $(7.33)^{* * *}$ & $(6.40)^{* * * *}$ & $(5.93)^{* * *}$ \\
\hline \multirow[t]{2}{*}{ DIST $_{i j}$} & -1.781 & -1.629 & -0.791 & -0.612 & -2.383 & -2.131 \\
\hline & $(17.21)^{* * *}$ & $(16.33)^{* * *}$ & $(5.25)^{* * *}$ & $(5.82) * * *$ & $(16.49) * * *$ & $(15.91) * * *$ \\
\hline \multirow{2}{*}{$\mathbf{B R D}_{\mathrm{ij}}$} & 0.235 & 0.219 & 0.194 & 0.163 & 1.172 & 1.695 \\
\hline & $(11.95)^{* * *}$ & $(12.05)^{* * *}$ & $(5.30)^{* * *}$ & $(5.65)^{* * *}$ & $(10.87) * * *$ & $(10.93) * * *$ \\
\hline \multirow[t]{2}{*}{$\mathbf{E T N}_{\mathrm{ij}}$} & 0.049 & 0.038 & 0.203 & 0.221 & 0.123 & -0.115 \\
\hline & $(0.83)$ & $(0.63)$ & $(2.31)^{* *}$ & $(2.76)^{* *}$ & $(1.56)$ & $(1.04)$ \\
\hline \multirow[t]{2}{*}{$\mathbf{S T}_{\text {it }}$} & - & 0.287 & & 0.510 & & -0.048 \\
\hline & - & $(3.52)^{* * *}$ & & $(0.83)$ & & $(0.58)$ \\
\hline \multirow[t]{2}{*}{$\mathbf{S T}_{\mathbf{j t}}$} & - & -0.113 & & 0.057 & & -0.037 \\
\hline & - & $(1.35)$ & & $(0.60)$ & & $(0.15)$ \\
\hline$\lambda_{t}$ & yes & yes & yes & yes & yes & yes \\
\hline \multirow[t]{2}{*}{ Residuals } & 1.000 & 1.000 & 1.000 & 1.000 & 1.000 & 1.000 \\
\hline & $(68.88)^{* * *}$ & $(65.97)^{* * *}$ & $(41.96)^{* * *}$ & $(40.82)^{* * *}$ & $(49.38) * * *$ & $(48.86)^{* * *}$ \\
\hline \multirow[t]{2}{*}{ Constant } & -0.035 & -0.195 & -1.104 & -1.576 & -0.018 & 0.182 \\
\hline & $(0.12)$ & $(0.61)$ & (1.49) & $(1.85)^{*}$ & $(0.03)$ & $(0.24)$ \\
\hline Observations & 1026 & 1026 & 513 & 513 & 513 & 513 \\
\hline R-squared & 0.80 & 0.83 & 0.71 & 0.75 & 0.82 & 0.87 \\
\hline \multicolumn{7}{|c|}{ t statistics in parentheses } \\
\hline
\end{tabular}

Note: FEVD stands for the Fixed Effects Decomposition method.

\section{Conclusions}

The aim of this paper was to analyse the relationship between environmental regulation and trade flows, more precisely whether the implementation of more stringent regulations has affected international competitiveness and decreased the exports of Romania towards its trading partners in the EU-27. We estimated gravity models to investigate separately the effects of 
environmental stringency on total trade (exports and imports), on pollution intensive trade and on pollution intensive trade related to non-resource-based trade.

In most cases the environmental stringency variable in exporting countries is found to have a positive and significant effect, in contrast with the haven hypothesis which implies that stricter environmental regulation decreases exports and increases imports. However, there is no evidence of such an effect in the case of "dirty" trade, possibly because of a comparative advantage such that stricter environmental policies do not affect competitiveness significantly. Other factors, such a labour costs, presumably play a much more important role, environmental costs representing a very small percentage of total production costs. 


\section{References}

[1] Anderson, J. E. (1979), 'A Theoretical Foundation for the Gravity Equation', American Economic Review 69(1), 106-116.

[2] Anderson, J. E. and E. van Wincoop, 2003. "Gravity with Gravitas: A Solution to the Border Puzzle," American Economic Review, American Economic Association, vol. 93(1), pages $170-192$.

[3] Copeland, B.R. and S. Taylor (2003) "Trade and the Environment: Theory and Evidence". Princeton Series in International Economics. Princeton and Oxford: Princeton University Press

[4] Ederington, J. and J. Minier (2003). "Is Environmental Policy a Secondary Trade Barrier? An Empirical Analysis". Canadian Journal of Economics 36(1), 137-154

[5] Ederington J, Levinson A and Minier J, 2005. "Footloose and Pollution-Free," The Review of Economics and Statistics, MIT Press, vol. 87(1), pages 92-99, 01

[6] Harris M.N., L. Kónya, and L. Mátyás (2002) "Modelling the Impact of Environmental Regulations on Bilateral Trade Flows: OECD, 1990-1996”. The World Economy,25(3), 387-405.

[7] Helpman, E. and P. Krugman (1985), Market Structure and Foreign Trade. Cambridge, Massachusetts:MIT Press

[8] Jug J. and D. Mirza, 2005. "Environmental Regulations in Gravity Equations: Evidence from Europe," The World Economy, Blackwell Publishing, vol. 28(11), 1591-1615.

[9] Levinson A and M. S. Taylor, 2008. "Unmasking The Pollution Haven Effect," International Economic Review, 49(1), pages 223-254, 02

[10] Linnemann, H. (1966), An Econometric Study of International Trade Flows. Netherlands: North- Holland Publishing Company.

[11] Low, P. and A. Yeats (1992), "Do "Dirty" Industries Migrate?" In: P. Low, ed. "International Trade and the Environment", World Bank Discussion Papers, 159

[12] Plumper, T. and Troeger, V.E. (2004). "The estimation of time-invariant variables in panel analyses with unit fixed effects". Social Science Research Network, Working Paper. 
[13] Tinbergen, J. (1962), Shaping the World Economy: Suggestions for an International Economic Policy. New York: The Twentieth Century Fund.

[14] Tobey, J. A. (1990). "The Effects of Domestic Environmental Policies on Patterns of World Trade: An Empirical Test”. Kyklos 43(2), 191-209.

[15] Van Beers, C. and J.C.J.M Van den Bergh (1997), “An Empirical Multi-Country Analysis of the Impact of Environmental Regulations on Foreign Trade Flows", Kyklos 50(1), 29-46

[16] Van Beers, C. and J.C.J.M Van den Bergh (2000), "The Impact of Environmental Policy on Foreign Trade: Tobey revisited with a Bilateral Flow Model," Tinbergen Institute Discussion Papers 00-069/3, Tinbergen Institute

[17] Xu, X. (2000). "International Trade and Environmental Regulation: Time Series Evidence and Cross Section Test”. Environmental and Resource Economics 17,233-257 


\section{DAVIDSON INSTITUTE WORKING PAPER SERIES - Most Recent Papers}

The entire Working Paper Series may be downloaded free of charge at: www.wdi.umich.edu

CURRENT AS OF $7 / 1 / 10$

\begin{tabular}{|c|c|c|}
\hline Publication & Authors & Date \\
\hline $\begin{array}{l}\text { No. 995: Environmental Regulation and Competitiveness: } \\
\text { Evidence from Romania }\end{array}$ & $\begin{array}{l}\text { Guglielmo M. Caporale, } \\
\text { Christophe Rault, Robert Sova \& } \\
\text { Anamaria Sova }\end{array}$ & June 2010 \\
\hline $\begin{array}{l}\text { No. 994: Pollution Abatement And Control Expenditure In Romania: } \\
\text { A Multilevel Analysis }\end{array}$ & $\begin{array}{c}\text { Guglielmo M. Caporale, } \\
\text { Christophe Rault, Robert Sova \& } \\
\text { Anamaria Sova }\end{array}$ & June 2010 \\
\hline $\begin{array}{l}\text { No. 993: Do Innovative Workplace Practices Foster Mutual Gains? } \\
\text { Evidence From Croatia }\end{array}$ & Derek Jones and Srecko Goic & May 2010 \\
\hline $\begin{array}{l}\text { No. 992: Firm And Employee Effects Of An Enterprise Information } \\
\text { System: Micro-Econometric Evidence }\end{array}$ & $\begin{array}{l}\text { Derek Jones, Panu Kalmi } \\
\text { and Antti Kauhanen }\end{array}$ & June 2010 \\
\hline $\begin{array}{l}\text { No. 991: Catching-up and inflation in Europe: Balassa- } \\
\text { Samuelson, Engel's Law and other Culprits }\end{array}$ & Balázs Égert & June 2010 \\
\hline $\begin{array}{l}\text { No. 990: UNLOCKING PRODUCTIVE ENTREPRENEURSHIP IN AFRICA'S LEAST } \\
\text { DEVELOPED COUNTRIES }\end{array}$ & Zuzana Brixiova & June 2010 \\
\hline $\begin{array}{l}\text { No. 989: The VARying Effect of Foreign Shocks in Central \& Eastern } \\
\text { Europe }\end{array}$ & $\begin{array}{l}\text { Rebeca Jimenez-Rodriguez, } \\
\text { Amalia Morales-Zumaquero } \\
\text { \& Balazs Egert }\end{array}$ & May 2010 \\
\hline $\begin{array}{l}\text { No. 988: Implications of Bank Ownership for the Credit Channel of } \\
\text { Monetary Policy Transmission: Evidence from India }\end{array}$ & $\begin{array}{l}\text { Sumon K. Bhaumik, Vinh Dang } \\
\text { and Ali M. Kutan }\end{array}$ & May 2010 \\
\hline $\begin{array}{l}\text { No. 987: Mother or motherland: Can a government have an impact on } \\
\text { educational attainment of the population? Preliminary evidence from } \\
\text { India }\end{array}$ & $\begin{array}{l}\text { Sumon Kumar Bhaumik and } \\
\text { Manisha Chakrabarty }\end{array}$ & May 2010 \\
\hline $\begin{array}{l}\text { No. 986: Does FDI spur innovation, productivity and knowledge sourcing } \\
\text { by incumbent firms? Evidence from manufacturing industry in Estonia }\end{array}$ & Priit Vahter & April 2010 \\
\hline No. 985: Exports and Property Prices in France: Are They Connected? & $\begin{array}{c}\text { Balazs Egert and } \\
\text { Rafal Kierzenkowski }\end{array}$ & May 2010 \\
\hline $\begin{array}{l}\text { No. 984: Methodologies of Analyzing Inter-Regional Income Inequality } \\
\text { and Their Applications to Russia }\end{array}$ & Konstantin Gluschenko & April 2010 \\
\hline $\begin{array}{l}\text { No. 983: Foreign News and Spillovers in Emerging European Stock } \\
\text { Markets }\end{array}$ & Evzen Kocenda and Jan Hanousek & $\begin{array}{l}\text { May } \\
2010\end{array}$ \\
\hline $\begin{array}{l}\text { No. 982: The Economic and Monetary Union's effect on (international) } \\
\text { trade: the case of Slovenia before euro adoption }\end{array}$ & $\begin{array}{l}\text { Aleksander Aristovnik and } \\
\text { Matevz Meze }\end{array}$ & $\begin{array}{l}\text { April } \\
2010\end{array}$ \\
\hline $\begin{array}{l}\text { No. 981: In Time of Troubles: Challenges and Prospects in the Middle } \\
\text { East and North Africa }\end{array}$ & Imed Drine & $\begin{array}{l}\text { April } \\
2010 \\
\end{array}$ \\
\hline No. 980: A Composite Leading Indicator of Tunisian Inflation & Mohamed Daly Sfia & $\begin{array}{l}\text { March } \\
2010\end{array}$ \\
\hline $\begin{array}{l}\text { No. 979: Financial stability, monetary autonomy and fiscal interference: } \\
\text { Bulgaria in search of its way, 1879-1913 }\end{array}$ & $\begin{array}{l}\text { Kalina Dimitrova and } \\
\text { Luca Fantacci }\end{array}$ & Feb 2010 \\
\hline $\begin{array}{l}\text { No. 978: The Supply Side of Innovation: H-1B Visa Reforms and US } \\
\text { Ethnic Invention }\end{array}$ & $\begin{array}{l}\text { William R. Kerr and } \\
\text { William F. Lincoln }\end{array}$ & Feb 2010 \\
\hline $\begin{array}{l}\text { No. 977: Data Collection Procedures Equivalence in International } \\
\text { Business Research }\end{array}$ & $\begin{array}{l}\text { Agnieszka Chidlow, } \\
\text { Anna Morgan-Thomas } \\
\text { and Pervez N. Ghauri }\end{array}$ & Feb 2010 \\
\hline $\begin{array}{l}\text { No. 976: Direct and Indirect Effects of FDI in Emerging European } \\
\text { Markets: A Survey and Meta-analysis }\end{array}$ & $\begin{array}{l}\text { Jan Hanousek, Evzen Kocenda } \\
\text { and Mathilde Maurel }\end{array}$ & $\begin{array}{l}\text { March } \\
2010\end{array}$ \\
\hline $\begin{array}{l}\text { No. 975: MODELING INSTITUTIONS, START-UPS AND PRODUCTIVITY DURING } \\
\text { TRANSITION }\end{array}$ & $\begin{array}{c}\text { Zuzana Brixiová and } \\
\text { Balázs Égert }\end{array}$ & Feb 2010 \\
\hline $\begin{array}{l}\text { No. 974: Pegging the future West African single currency in regard to } \\
\text { internal/external competitiveness: a counterfactual analysis }\end{array}$ & $\begin{array}{l}\text { Gilles Dufrénot and } \\
\text { Kimiko Sugimoto }\end{array}$ & Dec 2009 \\
\hline
\end{tabular}

